\title{
Integration of the Property of Weight into Infant's Manipulation
}

\author{
R.J. Itier, J. Provasi and H. Bloch
}

\section{(2) OpenEdition}

1 Journals

\section{Electronic version}

URL: http://journals.openedition.org/cpl/177

DOI: $10.4000 / \mathrm{cpl} .177$

ISSN: $1379-6100$

\section{Publisher}

Centre PsyCLÉ

\section{Printed version}

Date of publication: 1 April 2001

\section{Electronic reference}

R.J. Itier, J. Provasi and H. Bloch, «Integration of the Property of Weight into Infant's Manipulation », Current psychology letters [Online], 2001/1, 4 | 2001, Online since 05 September 2003, connection on 08 September 2020. URL : http://journals.openedition.org/cpl/177 ; DOl : https://doi.org/10.4000/cpl. 177

This text was automatically generated on 8 September 2020

(C) All rights reserved 


\title{
Integration of the Property of Weight into Infant's Manipulation
}

\author{
R.J. Itier, J. Provasi and H. Bloch
}

